\title{
A preliminary study of Salmonella spp., Listeria monocytogenes, Escherichia coli O157, Enterococcus faecalis and Clostridium spp. in Irish cattle
}

L. Russell ${ }^{1,2}$, C.P. Galindo ${ }^{1,2}$, P. Whyte ${ }^{2}$, D. Bolton ${ }^{1 \dagger}$

${ }^{1}$ Teagasc Food Research Centre, Ashtown, Dublin 15, Ireland

${ }^{2}$ School of Veterinary Medicine, University College Dublin, Belfield, Dublin 4, Ireland

Abstract

Although Salmonella spp., Escherichia coli 0157, Listeria monocytogenes, Enterococcus faecalis and Clostridium spp. present a significant food safety and/or spoilage issue for the beef sector, there are limited data on their prevalence in Irish cattle. The objectives of this preliminary study were to investigate the distribution (percentage of farms positive) of Salmonella spp., E. coli 0157, L. monocytogenes, E. faecalis and Clostridium spp. and the overall prevalence (\%) of these bacteria in cattle on a small cohort of Irish beef farms. A total of 121 fresh bovine faecal samples were obtained on 10 randomly selected beef farms in the Northeast of Ireland and tested for the target pathogens using standard culture-based methods. Presumptive positives were confirmed using previously published polymerase chain reaction (PCR) methods. Salmonella were not detected in any of the samples. E. coli 0157, L. monocytogenes, E. faecalis and Clostridium spp. were present on $50 \%, 40 \%, 100 \%$ and $100 \%$ of farms, respectively, with overall (all farms) prevalence rates in cattle of $9 \%, 8.2 \%, 61.9 \%$ and $87.6 \%$, respectively. This study suggests that $E$. coli 0157 may be more prevalent than previously thought and L. monocytogenes, E. faecalis and Clostridium spp. are widespread in Irish beef animals.

Keywords

Bovine • Escherichia coli $0157 \cdot$ faeces $•$ Listeria monocytogenes $•$ Salmonella

\section{Introduction}

Salmonella spp. are rod-shaped Gram-negative bacteria and the second most common cause of foodborne illness in the European Union (EU), with over 91,000 cases of salmonellosis reported in 2018 (EFSA and ECDC, 2019). According to Irish public health surveillance data for the same year, there were 363 confirmed cases in Ireland, 135 of which were hospitalised (HPSC, 2019). Salmonella spp. naturally colonise the intestinal tract of humans and animals, and human infection can occur when contaminated food or water is ingested, causing diarrhoea, cramps, vomiting and/or fever. Salmonella contamination of beef presents a significant risk in terms of food safety, with $3.2 \%$ of strongevidence (there is strong evidence implicating a particular food vehicle) food outbreaks attributed to meat and meat products and $2.6 \%$ of these linked to bovine meat (EFSA and ECDC, 2019).

Escherichia coli $\mathrm{O} 157$ is also a Gram-negative rod-shaped bacteria and a Shiga toxin-producing E. coli (STEC), which can cause foodborne illness characterised by diarrhoea, haemorrhagic colitis (bloody diarrhoea) and in more severe cases, haemolytic uraemic syndrome. This pathogen has a low infectious dose, with 966 confirmed STEC cases reported in Ireland in 2018 (EFSA and ECDC, 2019), an increase from the previous year's figure of 923 confirmed cases (205 of which were attributed to 0157), 295 hospitalisations and 4 deaths (HPSC, 2018). Contaminated, undercooked ground beef is commonly associated with E. coli O157-related foodborne illness, while water and ready-to-eat products contaminated with bovine faeces are also important sources (EFSA and ECDC, 2019).

Listeria monocytogenes is a Gram-positive, facultative anaerobe. Although L. monocytogenes is not a common foodborne pathogen, almost half of listeriosis cases result in hospitalisation, and approximately $15 \%$ end in fatality (EFSA and ECDC, 2019). There were 22 confirmed cases in 2018 in Ireland (HPSC, 2019). Listeriosis causes fever and diarrhoea similar to other foodborne pathogens, but in immunocompromised individuals, elderly people and pregnant women, more severe issues including preterm labour, miscarriage and/or death may occur (CDC, 2019). 
Enterococci, and more specifically Enterococcus faecalis, are Gram-positive cocci and opportunistic pathogens that are naturally present in the intestinal tract of humans and animals. While enterococci have been linked to waterborne outbreaks, the incidence is significantly lower than most bacterial pathogens under surveillance in the EU, with just one incidence reported in 2018 (EFSA and ECDC, 2019).

Clostridium spp. are a genus of spore-forming, obligate anaerobic Gram-positive bacteria that are naturally part of the gut microbiota of animals and include species that are of pathogenic and food spoilage concern. Clostridioides difficile, Clostridium perfringens and Clostridium botulinum are important pathogens, while species such as Clostridium estertheticum and Clostridium gasigenes cause significant spoilage of vacuum-packaged beef (Reid et al., 2017).

Bacteria in bovine faeces can be readily transferred to carcasses during slaughter and processing (Monaghan et al., 2012). Previous Irish studies have reported that $0.75 \%$ of hides (Khen et al., 2014), 0.25\% (McEvoy et al., 2003a) and $7.6 \%$ (Khen et al., 2014) of carcasses and 3.8\% of beef products (Khen et al., 2014) are contaminated with Salmonella spp. The corresponding figures for E. coli 0157 are $17.6 \%$ on hides and $0.7-3.2 \%$ on carcasses (Thomas et al., 2012) with $2.4-3.0 \%$ of beef products being contaminated with this pathogen (Cagney et al., 2004; Carney et al., 2006). L. monocytogenes has also been reported on bovine hides $(14 \%)$, carcasses $(27 \%)$ and in beef products $(29 \%)$ (Khen et al., 2015), but there are little or no data for $E$. faecalis or Clostridium spp.

The objectives of this preliminary study were to investigate the distribution (percentage of farms positive) of Salmonella spp., E. coli O157, L. monocytogenes, E. faecalis and Clostridium spp. and the overall prevalence (\%) of these bacteria in cattle on a small cohort of Irish beef farms.

\section{Materials and methods}

\section{Sampling}

Ten beef farms in county Meath in the Northeast of Ireland participated in this study including nine privately owned beef farms (randomly selected from the Teagasc client database), and the Teagasc beef research farm at Grange, Dunsany, Co. Meath. Testing took place during the late Spring and Summer months when the animals were on grass. All samples were obtained from the same herd in a single field. Ten freshly voided faecal samples (the first 10 observed by the research team) were obtained on eight of the farms. As one of the private farms and the Teagasc farm were larger than the others with multiple herds, 16 and 25 samples were obtained, respectively. Samples were obtained using a sterile scoop (Sterileware; Fisher Scientific, Dublin, Ireland) taking care to only remove material from the top of the faecal pile. All samples were transported in sterile containers (VWR, Dublin, Ireland) to the laboratory in a cool box at $2-4^{\circ} \mathrm{C}$ within $2 \mathrm{~h}$ and processed the same day.

\section{Microbiological analysis}

\section{Salmonella spp.}

Exactly $25 \mathrm{~g}$ of faeces was added to $225 \mathrm{~mL}$ Buffered Peptone Water (BPW; Oxoid, Fannin Ltd., Dublin, Ireland) and stomached (Colworth Seward Stomacher 80, Worthing, West Sussex, England) for $60 \mathrm{~s}$. Following incubation at $37^{\circ} \mathrm{C}$ for $24 \mathrm{~h}, 100 \mu \mathrm{L}$ of pre-enriched sample was plated onto Modified Semi-Solid Rappaport Vassiliadis (MSRV; Oxoid, Fannin Ltd., Dublin, Ireland) medium with Novobiocin supplement (20 mg/L; Oxoid, Fannin Ltd., Dublin, Ireland). Samples were incubated at $42^{\circ} \mathrm{C}$ for 24 and 48 h. Presumptive Salmonella colonies that exhibited haloed growth were streaked onto Xylose Lysine Deoxycholate (XLD) agar (Oxoid, Fannin Ltd., Dublin, Ireland) and incubated at $37^{\circ} \mathrm{C}$ for $24 \mathrm{~h}$ (ISO 6579-1:2017). Plates were inspected for growth, and typical colonies (red colonies with some having black centres) were plated on tryptone soya agar (TSA). DNA was extracted using the DNeasy Blood \& Tissue Kit (Qiagen, Manchester, UK) and frozen at $-80^{\circ} \mathrm{C}$ for subsequent confirmation by polymerase chain reaction (PCR). Isolates were subjected to real-time PCR using the Lightcycler 480 (Roche Diagnostics, Basel, Switzerland) as described by Pathmanathan et al. (2003).

\section{E. coli O157}

Enrichment for $E$. coli 0157 was carried out using modified tryptone soya broth (mTSB) with cefixime $(50 \mu \mathrm{g} / \mathrm{L})$ and vancomycin (6 mg/L) (Oxoid, Fannin Ltd., Dublin, Ireland). A $25-g$ quantity of each sample was added to $225 \mathrm{~mL}$ of $\mathrm{mTSB}$ and stomached for $60 \mathrm{~s}$. The samples were incubated at $37^{\circ} \mathrm{C}$ for $24 \mathrm{~h}$. Following this, immunomagnetic separation (IMS; Dynal ${ }^{\circledR}$ BeadRetriever, Thermo Fisher Scientific, Waltham, MA, USA) was carried out, and samples were plated on Sorbitol MacConkey agar supplemented with cefixime-tellurite (CTSMAC; Oxoid, Fannin Ltd., Dublin, Ireland) before incubation at $37^{\circ} \mathrm{C}$ for $24 \mathrm{~h}$. Suspect colonies (colourless round colonies) were streaked onto both eosin methylene blue agar (EMB; Oxoid, Fannin Ltd., Dublin, Ireland) and plate count agar (PCA; Oxoid, Fannin Ltd., Dublin, Ireland) and incubated at $37^{\circ} \mathrm{C}$ for $24 \mathrm{~h}$. The EMB plates were inspected for a green metallic sheen, and corresponding colonies on PCA plates were used to carry out agglutination testing using the Sifin Anti-coli 0157 sera test (Cruinn Diagnostics Ltd., Dublin, Ireland) (ISO 16654:2001(R2018)). Colonies that exhibited a green sheen and were agglutination positive were transferred to phosphate-buffered saline (PBS) and stored at $-20^{\circ} \mathrm{C}$ until extraction. DNA extraction was carried out using the Qiagen 
DNeasy Blood \& Tissue Kit and tested by PCR as described by Paton \& Paton (1998).

\section{L. monocytogenes}

Exactly $25 \mathrm{~g}$ of faeces was added to $225 \mathrm{~mL}$ of half-strength Fraser Broth (Oxoid, Fannin Ltd., Dublin, Ireland) and incubated overnight at $30^{\circ} \mathrm{C}$. Following incubation, $0.1 \mathrm{~mL}$ was placed into $10 \mathrm{~mL}$ of full-strength Fraser Broth (Oxoid, Fannin Ltd., Dublin, Ireland) prior to incubation at $37^{\circ} \mathrm{C}$ for $48 \mathrm{~h}$. After 24 and $48 \mathrm{~h}$, broths were streaked on Listeria Selective Oxford Agar (Oxoid, Fannin Ltd., Dublin, Ireland) and Brilliance Listeria Agar (Oxoid, Fannin Ltd., Dublin, Ireland). Following incubation at $37^{\circ} \mathrm{C}$ for $48 \mathrm{~h}$, presumptive positive colonies (black colonies with a black halo and sunken centre on the former and blue/green colonies with a halo on Brilliance Listeria Agar) were streaked onto PCA and incubated at $37^{\circ} \mathrm{C}$ for $24 \mathrm{~h}$. Presumptive colonies were selected, DNA was extracted using the Qiagen DNeasy Blood \& Tissue Kit and tested using the PCR protocol of Terzi et al. (2015).

\section{E. faecalis}

Exactly $25 \mathrm{~g}$ of each faecal sample was added to $225 \mathrm{~mL} \mathrm{BBL}$ Enterococcosel Broth (Becton Dickinson, Limerick, Ireland) and incubated at $37^{\circ} \mathrm{C}$ for $24 \mathrm{~h}$. The enrichment broths were plated on Slanetz and Bartley Agar (Oxoid, Fannin Ltd., Dublin, Ireland) and incubated at $37^{\circ} \mathrm{C}$ for $24 \mathrm{~h}$, followed by $44^{\circ} \mathrm{C}$ for an additional $24 \mathrm{~h}$. Pink colonies were streaked on PCA and stabbed in rows into well-dried Bile Aesculin Agar (BAA; Oxoid, Fannin Ltd., Dublin, Ireland) plates. The PCA plates were then incubated at $37^{\circ} \mathrm{C}$ for $24 \mathrm{~h}$, while BAA plates were incubated at $44^{\circ} \mathrm{C}$ for the same time period. Colonies that exhibited aesculin hydrolysis (more than half the agar plates turned dark brown) were considered presumptive positives and single colonies from corresponding PCA were selected for DNA extraction. Extraction was carried out using the Qiagen DNeasy Blood \& Tissue Kit, and samples were frozen at $-80^{\circ} \mathrm{C}$ prior to PCR (Dutka-Malen et al., 1995).

\section{Clostridium spp.}

Exactly $25 \mathrm{~g}$ of each faecal sample was added to $225 \mathrm{~mL}$ of Maximum Recovery Diluent (MRD), stomached and a serial dilution prepared, before plating on Reinforced Clostridial Agar (RCA; Oxoid, Fannin Ltd., Dublin, Ireland). Plates were incubated anaerobically, using Oxoid Anaerogen sachets (Oxoid, Fannin Ltd., Dublin, Ireland) and BioMérieux GENbox jars (bioMérieux UK Ltd., Hampshire, UK), at $37^{\circ} \mathrm{C}$ for $48 \mathrm{~h}$. Suspect colonies were transferred to Columbia Blood Agar (CBA; Oxoid, Fannin Ltd., Dublin, Ireland) supplemented with $5 \%$ defibrinated horse blood (Cruinn Diagnostics, Dublin, Ireland). Following anaerobic incubation of these plates at $37^{\circ} \mathrm{C}$ for $24 \mathrm{~h}$, colonies were inspected for haemolysis, and suspect colonies selected for DNA extraction and PCR. DNA extraction was carried out using Qiagen DNeasy Blood \& Tissue Kit and subjected to real-time PCR using group-specific primers (TibMolBiol, Berlin, Germany) to target and detect the 16S rRNA of Cluster 1 Clostridium spp. (Song et al., 2004).

\section{Results}

The individual results for each farm are shown in Table 1. Salmonella spp. were not detected on any of the farms. Bovine faecal samples on Farm 1 tested positive for $E$. faecalis and Clostridium spp. but the other target bacteria were not detected. A similar pattern was obtained on Farms 4, 6, 7 and 8. E. coli O157, L. monocytogenes, E. faecalis and Clostridium spp. were detected in the faecal samples on Farms

Table 1: The number and percentage of pathogen-positive samples in bovine faecal samples on each farm

\begin{tabular}{|c|c|c|c|c|c|c|c|}
\hline Farm & $N$ & Location & Salmonella spp. & $\begin{array}{l}\text { Escherichia } \\
\text { coli } 0157\end{array}$ & $\begin{array}{c}\text { Listeria } \\
\text { monocytogenes }\end{array}$ & $\begin{array}{c}\text { Enterococcus } \\
\text { faecalis }\end{array}$ & Clostridium spp. \\
\hline 1 & 10 & Lobinstown (Meath) & ND & ND & ND & $7(70 \%)$ & $10(100 \%)$ \\
\hline 2 & 10 & Castletown (Meath) & ND & $1(10 \%)$ & $5(50 \%)$ & $6(60 \%)$ & $10(100 \%)$ \\
\hline 3 & 10 & Castletown (Meath) & ND & $2(20 \%)$ & ND & $5(50 \%)$ & $10(100 \%)$ \\
\hline 4 & 10 & Rathcore (Meath) & ND & ND & ND & $3(30 \%)$ & $5(50 \%)$ \\
\hline 5 & 10 & Moynalty (Meath) & ND & $1(10 \%)$ & $1(10 \%)$ & $7(70 \%)$ & $10(100 \%)$ \\
\hline 6 & 10 & Wilkinstown (Meath) & ND & ND & ND & $6(60 \%)$ & $10(100 \%)$ \\
\hline 7 & 10 & Howthstown (Meath) & ND & ND & ND & $1(10 \%)$ & $10(100 \%)$ \\
\hline 8 & 10 & Fennor (Meath) & ND & ND & ND & $4(40 \%)$ & $10(100 \%)$ \\
\hline 9 & 16 & Castletown (Meath) & ND & $1(6 \%)$ & $1(6 \%)$ & $12(75 \%)$ & $16(100 \%)$ \\
\hline 10 & 25 & Grange (Meath) & ND & $6(24 \%)$ & $3(12 \%)$ & $24(96 \%)$ & $25(100 \%)$ \\
\hline
\end{tabular}

$N=$ number of samples tested; $N D=$ not detected. 


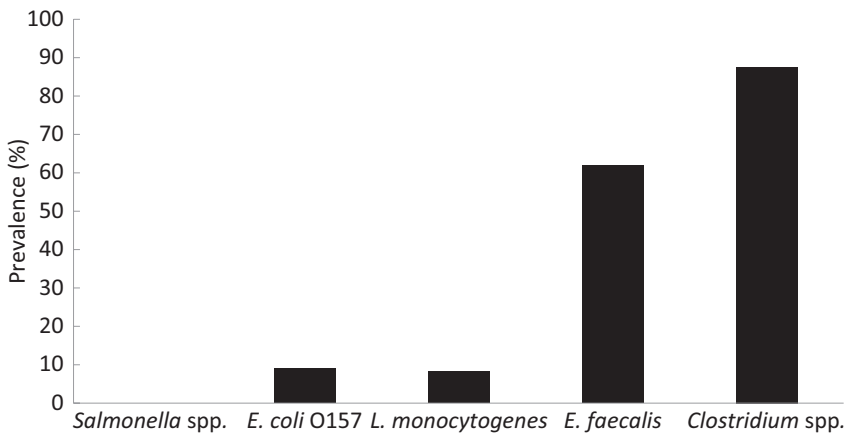

Figure 1. The overall prevalence (\%) of Salmonella spp., Escherichia coli O157, Listeria monocytogenes, Enterococcus faecalis and Clostridium spp. in the faecal samples.

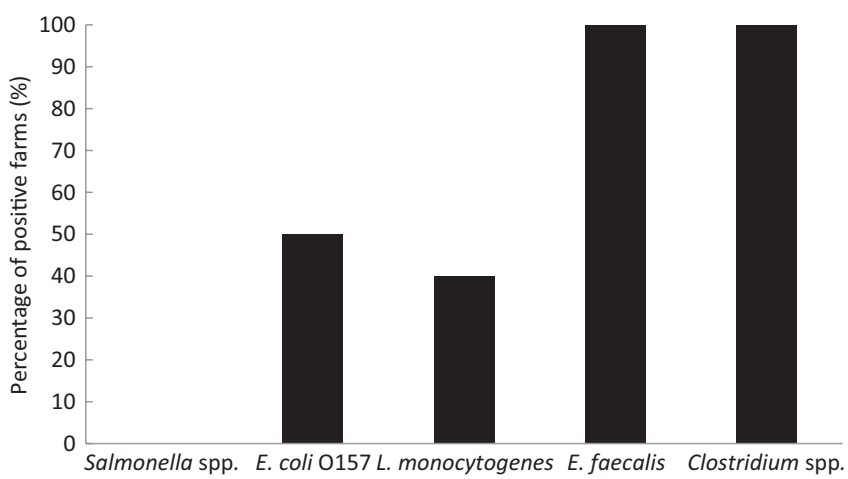

Figure 2. The percentage of Irish beef farms positive for Salmonella spp., Escherichia coli O157, Listeria monocytogenes, Enterococcus faecalis and Clostridium spp.

2, 5, 9 and 10. With the exception of $L$. monocytogenes, these bacteria were also present on Farm 3. The overall prevalence (\%) of Salmonella spp., E. coli O157, L. monocytogenes, E. faecalis and Clostridium spp. in the faecal samples is shown in Figure 1 and the percentage of farms positive for a given pathogen is shown in Figure 2. Clostridium spp. were particularly common, being detected in $87.6 \%$ of samples followed by E. faecalis $(61.9 \%)$, E. coli 0157 (9\%), L. monocytogenes $(8.2 \%)$ and Salmonella spp. (0\%). Clostridium spp. and E. faecalis were widely distributed being detected on all farms, E. coli $\mathrm{O} 157$ on half and L. monocytogenes on $40 \%$ of farms.

\section{Discussion}

Even allowing for the small sample size (121 samples), the absence of Salmonella spp. in the samples tested was unexpected. McEvoy et al. (2003a) reported a prevalence of $2 \%$ for Salmonella spp. in cattle in the Republic of Ireland, while
Madden et al. (2007) obtained a 3\% rate in Northern Ireland. In the United Kingdom, where bovine animal breeds, husbandry practices and weather conditions are similar to Ireland, Hutchison et al. (2004) reported a 7.7\% Salmonella prevalence in fresh bovine faeces. In contrast, Salmonella prevalence as low as $0.2 \%$ has been previously reported in bovine faeces in the USA (Rodriguez et al., 2006). While season, feed type and animal husbandry all influence Salmonella carriage and shedding in bovine animals (Rhoades et al., 2009), sampling isolated individual faecal deposits in fields also results in lower detection rates as these are not cross-contaminated by waste from other animals (Arnold et al., 2015). Moreover, the impact of good animal husbandry, biosecurity and hygiene practices by Teagasc client farmers cannot be ruled out, although validation would require further investigation.

The overall prevalence of $E$. coli 0157 of $9 \%$ in bovine faeces was higher than the $0.7-2.4 \%$, previously reported in Ireland (McEvoy et al., 2003b; Thomas et al., 2012) but similar to the $7.1-8.3 \%$ reported in the UK (Gunn et al., 2007; Smith et al., 2009, 2016). STEC, especially serogroup 0157, are a common cause of gastrointestinal illness around the world and are frequently associated with severe illness including haemorrhagic colitis and haemolytic uraemic syndrome. Bacteria in faeces contaminate hides and are readily transferred to the carcasses during hide removal in the abattoir (Tergny \& Bolton, 2006). Beef is therefore a major source of E. coli $O 157$ infections in the EU (EFSA, 2020) and the relatively high prevalence of these bacteria observed in this study is a cause for concern.

Data on the prevalence of $L$. monocytogenes in bovine faeces are also limited. The $L$. monocytogenes prevalence obtained in this study $(8.2 \%)$ is midway between the prevalence of $4.8 \%$ reported in a Northern Irish Study (Madden et al., 2007 ) and $12 \%$ reported in dairy cows in Ireland (Fox et al., 2009). In contrast, Nightingale et al. (2004) reported a $29.4 \%$ overall faecal prevalence in 323 bovine faecal samples examined as part of a US study. Previous studies reported that $L$. monocytogenes prevalence in minced beef products in Dublin ranged from $4.7 \%$ to $16 \%$ (Sheridan et al., 1994 , 1997). However, this research is more than 20 years old and to the best of our knowledge more up-to-date data are not available. As there are multiple sources of $L$. monocytogenes along the beef processing chain, the impact of bovine faecal contamination rates on the risk to public health is unknown.

E. faecalis was present in $61.9 \%$ of bovine faecal samples tested. This organism is not widely studied in cattle, and to the best of our knowledge, comparative data are not available for Ireland or the UK. However, prevalence rates of $13.3 \%$ and $43.3 \%$ have been previously reported for Belgian cattle (de Jong et al., 2018) and Latvian calves (Terentjeva et al., 2019), respectively. Enterococcal species are common constituents 
of the intestinal flora of many animal species. However, in recent years, enterococci, especially multiple antibioticresistant $E$. faecalis, have been associated with nosocomial bloodstream, urinary tract and surgical wound infections, within the hospital environment, rather than food, serving as the source of infection (Moellering, 1992). Thus, the high prevalence in bovine faeces may not present a direct risk of infection but may serve as a source of antibiotic resistance determinants for other pathogens (Weigel et al., 2003).

Of all the organisms examined in our study, Clostridium spp. were the most frequently detected, with $87.6 \%$ of samples testing positive. PCR confirmation focused on targeting Cluster 1 clostridia, which includes pathogenic species: $C$. botulinum, Clostridium tetani, C. perfringens, as well as C. difficile, and spoilage organisms, C. estertheticum and C. gasigenes (Song et al., 2004). Comparison of this figure with previously published data is difficult, as no other studies focused on Cluster 1 clostridial species, but specifically targeted C. difficile, C. botulinum or C. perfringens (Cox et al., 2005; Bartels et al., 2010; Kruger et al., 2012). However, previous Irish research reported C. estertheticum and C. gasigenes in $17.9 \%$ and $25.4 \%$ of bovine faecal samples, respectively (Moschonas et al., 2009). A more recent study found C. difficile in $6.7 \%$ of bovine faeces (Marcos et al., 2021). Further research is required to characterise the Clostridium spp. in bovine faeces before the potential impact of such high prevalence on food safety and spoilage can be assessed.

It was concluded that, although differences in study design, animal age, diet, seasonality and the detection method affect the prevalence in specific bacteria in bovine faecal surveys (Bolton et al., 2012), Salmonella spp., E. coli 0157 and L. monocytogenes may be present in beef animals but usually at a low $(<10 \%)$ prevalence. In contrast, E. faecalis and Clostridium spp. are more common, perhaps reflecting their ubiquitous distribution in farming environments.

\section{Acknowledgements}

This study was funded by the Food Institute Research Measure administered by the Department of Agriculture, Food and the Marine (Project 14/SF/487). Ms. Lauren Russell was supported by the Teagasc Walsh Scholarship Programme (number 2014239).

\section{References}

Arnold, M.E., Gosling, J.R., Martelli, F., Mueller-Doblies, D. and Davies, R.H. 2015. Evaluation of the sensitivity of faecal sampling for detection of monophasic Salmonella typhimurium and other
Salmonella in cattle and pigs. Epidemiology and Infection 143: 1681-1691.

Bartels, C.J.M., Holzhauer, M., Jorritsma, R., Swart, W.A.J.M. and Lam, T.J.G.M. 2010. Prevalence, prediction and risk factors of enteropathogens in normal and non-normal faeces of young Dutch dairy calves. Preventive Veterinary Medicine 93: 162-169.

Bolton, D.J., O’Neill, C.J. and Fanning, S. 2012. A preliminary study of Salmonella, verocytotoxigenic Escherichia colilEscherichia coli 0157 and campylobacter on four mixed farms. Zoonoses and Public Health 59: 217-228.

Cagney, C., Crowley, H., Duffy, G., Sheridan, J.J., O’Brien, S., Carney, E., Anderson, W., McDowell, D.A., Blair, I.S. and Bishop, R.H. 2004. Prevalence and numbers of Escherichia coli 0157:H7 in minced beef and beef burgers from butcher shops and supermarkets in the Republic of Ireland. Food Microbiology 21: 203-212.

Carney, E., O'Brien, S.B., Sheridan, J.J., McDowell, D.A., Blair, I.S. and Duffy, G. 2006. Prevalence and level of Escherichia coli 0157 on beef trimmings, carcasses and boned head meat at a beef slaughter plant. Food Microbiology 23: 52-59.

CDC. 2019. Listeria (Listeriosis) [Online]. Available online: https:// www.cdc.gov/listeria/index.html [Accessed 16 February 2020].

Cox, P., Griffith, M., Angles, M., Deere, D. and Ferguson, C. 2005. Concentrations of pathogens and indicators in animal feces in the Sydney watershed. Applied Environmental Microbiology 71: 5929-5934.

de Jong, A., Simjee, S., Garch, F.E., Moyaert, H., Rose, M., Youala, M. and Dry, M. 2018. Antimicrobial susceptibility of enterococci recovered from healthy cattle, pigs and chickens in nine EU countries (EASSA Study) to critically important antibiotics. Veterinary Microbiology 216: 168-175.

Dutka-Malen, S., Evers, S. and Courvalin, P. 1995. Detection of glycopeptide resistance genotypes and identification to the species level of clinically relevant enterococci by PCR. Journal of Clinical Microbiology 33: 24-27.

EFSA and ECDC (European Food Safety Authority and European Centre for Disease Prevention and Control). 2019. The European Union One Health 2018 Zoonoses Report. EFSA Journal 17: e05926. Available online: https://doi. org/10.2903/j.efsa.2019.5926.

EFSA (European Food Safety Authority). 2020. Scientific Opinion on the pathogenicity assessment of Shiga toxin-producing Escherichia coli (STEC) and the public health risk posed by contamination of food with STEC. EFSA Journal 18: 5967, 105. Available online: https://doi.org/10.2903/j.efsa.2020.5967. ISSN: 1831-4732.

Fox, E., O'Mahony, T., Clancy, M., Dempsey, R., O'Brien, M. and Jordan, K. 2009. Listeria monocytogenes in the Irish dairy farm environment. Journal of Food Protection 72: 1450-1456.

Gunn, G.J., McKendrick, I.J., Ternent, H.E., Thomson-Carter, F., Foster, G. and Synge, B.A. 2007. An investigation of factors associated with the prevalence of verocytotoxin producing 
Escherichia coli 0157 shedding in Scottish beef cattle. The Veterinary Journal 174: 554-564.

HPSC. 2018. Annual Epidemiological Report: VTEC infection in Ireland, 2017. Health Protection Surveillance Centre.

HPSC. 2019. Annual Epidemiological Report, 2018. Health Protection Surveillance Centre.

Hutchison, M.L., Walters, L.D., Avery, S.M., Synge, B.A. and Moore, A. 2004. Levels of zoonotic agents in British livestock manures. Letters in Applied Microbiology 39: 207-214.

ISO. 2017. ISO 6579-1:2017 Microbiology of the food chain horizontal method for the detection, enumeration and serotyping of Salmonella. International Organization for Standardization.

ISO. 2018. ISO 16654:2001(R2018) Microbiology of food and animal feeding stuffs - horizontal method for the detection of Escherichia coli O157. International Organization for Standardization.

Khen, B.K., Lynch, O.A., Carroll, J., McDowell, D.A. and Duffy, G. 2014. Prevalence and characteristics of Salmonella in the beef chain in the Republic of Ireland. Zoonoses and Public Health 61: 534-536.

Khen, B.K., Lynch, O.A., Carroll, J., McDowell, D.A. and Duffy, G. 2015. Occurrence, antibiotic resistance and molecular characterization of Listeria monocytogenes in the beef chain in the Republic of Ireland. Zoonoses and Public Health 62: 11-17.

Kruger, M., Grosse-Herrenthey, A., Schrodl, W., Gerlach, A. and Rodloff, A. 2012. Visceral botulism at dairy farms in Schleswig Holstein, Germany: prevalence of Clostridium botulinum in feces of cows, in animal feeds, in feces of the farmers, and in house dust. Anaerobe 18: 221-223.

Madden, R.H., Murray, K.A. and Gilmour, A. 2007. Carriage of four bacterial pathogens by beef cattle in Northern Ireland at time of slaughter. Letters in Applied Microbiology 44: 115-119.

Marcos, P., Whyte, P., Rogers, T., McElroy, M., Fanning, S., Frias, J., Burgess, C.M. and Bolton, D.J. 2021. The prevalence of Clostridioides difficile on farms, in abattoirs and in retail foods in Ireland. Food Microbiology 98: 103781, available online at: https:// www.sciencedirect.com/science/article/pii/S0740002021000460.

McEvoy, J.M., Doherty, A.M., Sheridan, J.J., Blair, I.S. and McDowell, D.A. 2003a. The prevalence of Salmonella spp. in bovine faecal, rumen and carcass samples at a commercial abattoir. Journal of Applied Microbiology 94: 693-700.

McEvoy, J.M., Doherty, A.M., Sheridan, J.J., Thomson-Carter, F.M., Garvey, P., McGuire, L., Blair, I.S. and McDowell, D.A. 2003b. The prevalence and spread of Escherichia coli O157:H7 at a commercial beef abattoir. Journal of Applied Microbiology 95: 256-266.

Moellering, R.C. 1992. Emergence of Enterococcus as a significant pathogen. Clinical Infection and Disease 14: 1173-1176.

Monaghan, Á., Byrne, B., Fanning, S., Sweeney, T., McDowell, D. and Bolton, D.J. 2012. Serotypes and virulotypes of non-O157 Shiga-toxin producing Escherichia coli (STEC) on bovine hides and carcasses. Food Microbiology 32: 223-229.
Moschonas, G., Bolton, D.J., Sheridan, J.J. and McDowell, D.A. 2009. Isolation and sources of 'blown pack' spoilage clostridia in beef abattoirs. Journal of Applied Microbiology 107: 616-624.

Nightingale, K.K., Schukken, Y.H., Nightingale, C.R., Fortes, E.D., Ho, A.J., Her, Z., Grohn, Y.T., McDonough, P.L. and Wiedmann, M. 2004. Ecology and transmission of Listeria monocytogenes infecting ruminants and in the farm environment. Applied and Environmental Microbiology 70: 4458-4467.

Pathmanathan, S.G., Cardona-Castro, N., Sanchez-Jimenez, M.M., Correa-Ochoa, M.M., Puthucheary, S.D. and Thong, K.L. 2003. Simple and rapid detection of Salmonella strains by direct PCR amplification of the hilA gene. Journal of Medical Microbiology 52: 773-736.

Paton, A.W. and Paton, J.C. 1998. Detection and characterization of Shiga toxigenic Escherichia coli by using multiplex PCR assays for stx1, stx2, eaeA, enterohemorrhagic E. coli hlyA, rfbO111, and rfbO157. Journal of Clinical Microbiology 36: 598-602.

Reid, R., Tyuftin, A.A., Kerry, J.P., Fanning, S., Whyte, P. and Bolton, D. 2017. Controlling blown pack spoilage using anti-microbial packaging. Foods 6: 67.

Rhoades, J.R., Duffy, G. and Koutsoumanis, K. 2009. Prevalence and concentration of verocytotoxigenic Escherichia coli, Salmonella enterica and Listeria monocytogenes in the beef production chain: a review. Food Microbiology 26: 357-376.

Rodriguez, A., Pangloli, P., Richards, H.A., Mount, J.R. and Draughon, F.A. 2006. Prevalence of Salmonella in diverse environmental farm samples. Journal of Food Protection 69: 2576-2580.

Sheridan, J.J., Duffy, G., McDowell, D.A. and Blair, I.S. 1994. The occurrence and initial numbers of Listeria in Irish meat and fish products and the recovery of injured cells from frozen products. International Journal of Food Microbiology 22: 105-113.

Sheridan, J.J., Duffy, G., McDowell, D.A. and Blair, I.S. 1997. Development of a surface adhesion immunofluorescent technique for the rapid isolation of Listeria monocytogenes and Listeria innocua from meat. Journal of Applied Microbiology 82: 225-232.

Smith, R.P., Ellis-Iversen, J., Snary, E.L., Clifton-Hadley, F.A. and Paiba, G.A. 2009. Factors influencing the presence and concentration of $E$. coli $\mathrm{O} 157$ and $E$. coli in farm waste on six cattle farms in North-West England. Journal of Applied Microbiology 106: 613-623.

Smith, R.P., Pollitt, W.J. and Paiba, G.A. 2016. A longitudinal study of risk factors for shedding of VTEC 0157 by young cattle in herds with known E. coli 0157 carriage. Epidemiology and Infection 144: 1818-1829.

Song, Y., Liu, C. and Finegold, S.M. 2004. Real-time PCR quantitation of clostridia in feces of autistic children. Applied and Environmental Microbiology 70: 6459-6465.

Terentjeva, M., Streikisa, M., Avsejenko, J., Trofimova, J., Kovalenko, K., Elferts, D. and Berzins, A. 2019. Prevalence and antimicrobial resistance of Escherichia coli, Enterococcus spp. and the major 
foodborne pathogens in calves in Latvia. Foodborne Pathogens and Disease 16: 35-41.

Tergny, A. and Bolton, D.J. 2006. Validation studies on an online monitoring system for reducing faecal and microbial contamination on beef carcasses. Food Control 17: 378-382.

Terzi, G., Gücükoğlu, A., Çadirci, Ö., Uyanik, T. and Alişarli, M. 2015. Serotyping and antibiotic susceptibility of Listeria monocytogenes isolated from ready-to-eat foods in Samsun, Turkey. Turkish Journal of Veterinary and Animal Sciences 39: 211-217.
Thomas, K.M., McCann, M.S., Collery, M.M., Logan, A., Whyte, P., McDowell, D.A. and Duffy, G. 2012. Tracking verocytotoxigenic Escherichia coli O157, O26, O111, 0103 and 0145 in Irish cattle. International Journal of Food Microbiology 153: 288-296.

Weigel, L.M., Clewell, D.B., Gill, S.R., Clark, N.C., McDougal, L.K., Flannagan, S.E., Kolonay, J.F., Shetty, J., Killgore, G.E. and Tenover, F.C. 2003. Genetic analysis of a high-level vancomycinresistant isolate of Staphylococcus aureus. Science 302: 1569-1571. 